\title{
Un inmenso filósofo platónico
}

\author{
EUGENIO TRÍAS
}

Al expulsar al artista mimético de su ciudad ideal generó Platón un equívoco trascendental que ha atravesado toda la empresa histórica del arte y de la filosofía de Occidente. La gran paradoja platónica estriba en que ese gesto tan desconsiderado no ha sido obstáculo para que artistas y poetas de todas las edades, antiguos y modernos, renacentistas, barrocos, románticos o vanguardistas hayan hallado en Platón el mejor aval de sus obras de creación. Ningún filósofo ha sido tan considerado y visitado por una nómina tan diversa y contrastada de artistas y literatos.

El escarnio de la paradoja consiste en que los creadores artísticos y literarios pasan por alto, como una humorada irónica de Platón, esa ominosa expulsión, que sin embargo parecería concernirles, mientras que a los filósofos (encumbrados a rango de monarcas) les sume en una especie de mala conciencia que provoca, por lo general, una agresividad constante contra ese ambiguo y, al parecer, poco aceptable fundador de la propia disciplina filosófica.

En el pasado siglo no hubo quien osara reconocerse seriamente platónico en ese gremio. En cambio abundó el consenso que lo convierte en chivo expiatorio entre filósofos. Platón es el gran villano de la filosofía del siglo XX: fundador de la 'sociedad cerrada' (Popper), iniciador de la historia de la metafísica y del divorcio del Arte y de la Verdad (Heidegger), responsable del olvido de la Archi-escritura y 
consiguiente gestación del Logo-Falo-centrismo (Derrida), paradigma de toda suerte de Meta-relato, etc. Todo filósofo que se precie descargó todas sus obsesiones negativas sobre ese padre fundador, iniciando un intento de parricidio con él que, sin embargo, se reveló 'fallido' (por usar la expresión de Emmanuele Severino).

Platón, gran filósofo y gran artista, sobrevuela con su tremenda ironía (del excelso comediante) a todos sus críticos del siglo veinte, evidenciando la ausencia de humor (y de sentido común) de la mayoría de los filósofos del pasado siglo, y no sólo de los epígonos.

¿Cómo no entender irónicamente su reflexión sobre el carácter subsidiario y secundario de la escritura frente a la Palabra Viva en un personaje (Platón) que no hizo otra cosa que pergeñar hermosísimos textos, en los que dejaba discurrir a un personaje de ficción, Sócrates, que sin embargo se negó a escribir? Sócrates, no se olvide, es un personaje de ficción. Su 'habla viva' es y existe en virtud de la gestación textual y de escritura de Platón. La filosofía sólo es tal si es escritura, pero no como teoría (en el modo gramatológico) sino como ejercicio y pragmática. La filosofía se encarna en la escritura: gran lección del fundador de esa tensa, difícil exploración ideal y conceptual que requiere sin embargo tiento, aventura y riesgo: su proyección poemática y ensayística; eso que todavía hoy podemos llamar, con orgullo, filosofía.

Se habla demasiado de la ironía socrática; se habla demasiado poco de la ironía platónica. La de un gran artista que fue también un gran filósofo; y que expulsó al artista mimético de su ciudad por la sencilla razón de que, con la estrechez de su mimético deleite en puras imágenes, o en meros relatos anecdóticos, se privó de esa gran tarea artístico-filosófica que consiste en hallar un nexo, difícil pero posible, entre la creación artística, la poièsis, fecundada por erōs, y la reflexión filosófica (logos). El filósofo rey era, también, artista regio: creador de formas artísticas que, sin embargo, en su condición poética de diálogos (por referirme al género elegido por el propio Platón) podían abrirse a un conocimiento difícil y arriesgado, siempre en el límite de lo incognoscible, el que permitía el viaje erótico, filo-sófico, hacia Ideas que eran, de hecho, aporías, grandes cuestiones necesarias de plantear pero de extrema dificultad en su abordaje y respuesta.

Platón puso el listón altísimo al concebir una unión asintótica de Arte y Verdad, o de Filosofía y Creación (poièsis) que en la tradición 
postplatónica se quebró. Yerra lamentablemente Heidegger en pensar que es Platón mismo quien sanciona ese divorcio. Un error trágico y genial, como que proviene del mejor poeta-filósofo del siglo pasado; como se pone en evidencia en ese gran monumento, al fin vertido en excelentísima traducción por Juan Luis Vermal a nuestra lengua, su célebre Nietzsche, que hoy puede ya leerse en español.

Una vez más el filósofo, en este punto, se deja llevar por las ideas vertidas en cierto texto en lugar de comprender, en términos de fino instinto lector, que el texto tiene sus recovecos, sus personajes, su drama interno. Platón no sancionó ese divorcio sino que escenificó una suerte de Ciudad Ideal en la que un arte carente de pensamiento, simplemente imitativo, sólo apto para mostrar imágenes y anécdotas, no tenía lugar (aun cuando tuviera como argumento de autoridad nombres como Homero o los trágicos). Más allá de la posible bybris platónica, o socrática, en su recuento, la idea es clara: sólo un arte y una literatura de conocimiento, en donde la experiencia se elabora y sublima en apertura filosófica, sólo un arte así merece el nombre de creación, poièsis, es decir, poesía. No puede jamás existir en esa ciudad platónica poesía en la que la experiencia no sea viaje y transición hacia el conocimiento; viaje filosófico. La poesía sólo es tal si es filosófica; la filosofía sólo se realiza si tiene antenas poéticas.

Por eso sólo existe quizá un inmenso filósofo platónico en toda nuestra tradición occidental: Nietzsche. Es decir, el filósofo que se reconoció a sí mismo como el más antiplatónico de los filósofos; el que en cierto modo condicionó a todos sus epígonos, incluso a los más grandes (Heidegger, por ejemplo), al asumir sin crítica el falaz corte histórico que Nietzsche propuso del extravío metafísico y nihilista propiciado por el propio Platón.

Pero Nietzsche logró, en Así babló Zaratustra, un extraordinario modo de conjugar, como Platón, la creación artística, poemática, con la iniciación filosófica hacia la sabiduría. Y lo hizo componiendo un poema lleno de enigmáticos símbolos que albergaban y protegían poderosas ideas metafísicas (voluntad de poder, vida, eterno retorno de lo igual, superhombre).

Unas ideas en las que sorprendentemente resucitaban muchas de las mejores ideas platónicas: la idea de erōs, o el gran anhelo de eternidad, como motor de la creación (voluntad de poder como voluntad de crear, poiesis). En mis libros El artista y la ciudad y Filosofía del futuro 
insistí en estos aspectos tan paradójicos y peculiares de la filosofía de Nietzsche: en su claro ascendiente platónico. Ese ascendiente se advierte, sobre todo, en el poema nietzscheano, debido al carácter creativo del mismo, a su condición de verdadera gestación poética (pero de poema iluminativo, o de poesía de conocimiento).

En cambio ese carácter se diluye y pierde en textos más decididamente 'críticos', en los que Nietzsche se dedica a filosofar 'con el martillo'. La voluntad de poder no es ya entonces anhelo inextinguible de creación y recreación, ni el eterno retorno es incitación a la re-creación (o a lo que suelo llamar en mis libros 'principio de variación'). La voluntad de poder deja de pensarse como poesía y poema y se concibe en el sentido, tosco, de voluntad de dominio y dominación, o voluntad gestadora de instrumentos de dominación (el Estado, en especial).

Pero en el gran poema escrito a miles de metros de altura por encima de los hombres, allí donde las mayores tragedias aparecen como comedias, esos conceptos adquieren un sentido bello, hermoso, afirmativo, que parece hacerlos brotar, de manera espontánea, del gran arsenal platónico de El banquete, Fedro o La república. Y es que Platón y Nietzsche son algo más que el comienzo y el cierre de la metafísica: son los dos pensadores pre- y post-metafísicos, todavía por descubrir, que pueden aun darnos indicación y dirección al pensar poético, y a la poesía filosófica, que este nuevo siglo y milenio espera (también en nuestras lenguas ibéricas, o iberoamericanas). 